\title{
「タコ」形アザシクロファンの分子認識特性と クロマトグラフィーへの応用
}

\author{
(1986 年 8 月 5 日受理)
}

村上幸人*・菊池純一・松浦猛夫

種々の眯水性ゲスト分子に対して induced-fit 型の包接特性を示すホスト分子である $N, N^{\prime}, N^{\prime \prime}$, N"llーテトラキス (10-カルボキシデシル)-2, 11,20,29-テトラアザ[3.3.3.3]パラシクロファン-1, 12, 19,

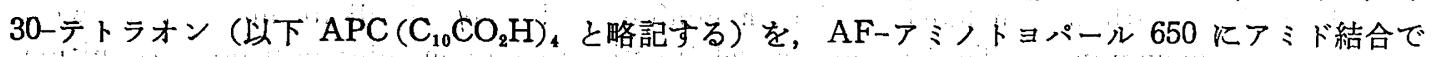
導入したクロマトグラフィ一用充填剂支調製した。溶離液としてはメタノー出と炭酸緩衝液 $(0.01 \mathrm{~mol}$ $\left.\mathrm{dm}^{-3}, \mathrm{pH} 10.0, \mu 0.10(\mathrm{KCl})\right)$ 混合溶媒を用い, 均一水溶液中に打ける $\mathrm{APC}\left(\mathrm{C}_{10} \mathrm{CO}_{2} \mathrm{H}\right)_{4}$ の包接 挙動が明らかにされている 6 種類の䟱水性ゲスト分子の分離特性を明らかにした。AF-アミノトヨパー ル 650 のアミノ基をすべてアセチル化した充填剤と比較した場合に, $\mathrm{APC}\left(\mathrm{C}_{10} \mathrm{CO}_{2} \mathrm{H}\right)_{4}$ の包接特性を 反映して静電相互作用と粟水性相互作用による新たな分離挙動が認められた。「タコ」形アザシクロフ フンを $\mathrm{APC}\left(\mathrm{C}_{10} \mathrm{CO}_{2} \mathrm{H}\right)$ ４の構造形態で担体に直接導入するよりも，その炭化水素鎖末端の 4 個のカル ボキシル基のらち 3 個をメチルエステルとして保護して樹脂に固定化することによって，より効果的な 分離機能が発現された。

\section{1 緒言}

シクロファン類は剛直な環骨格によってつくりだれる䟱水性 空間を有し、ゲスト識別能をるつホスト分子として近年興味の対

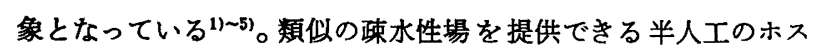
ト分子であるシクロデキストリン類の7にくらべて, シクロファン はその柾水性空間の分子設計にきわめて多様性がある点が大きな 特徽である。以前, 著者らは一連の [20]および [10.10] パラシ クロフ、ン誘導体を合成し，それらが加水分解酵素における酵素 と基質間のホスト・ゲスト相互作用に類似して有効なゲスト分子 識別能をるつホスト分子としての機能を発現することを明らかに している214。また，テトラアザ [3.3.3.3] シクロフォンに複数の

九州大学工学部合成化学科, 812 福岡市東区箱崎

1）平岡道夫, 柳田博明, 小原正明, 古賀憲司綃, “ホスト・ ゲストケミストリー”, 講談社 (1984) p. 168.

2）村上幸人, 砂本順三, “酵素・生体膜モデルの化学”, 南江 堂 (1981) p. 40 .

3) I. Tabushi, K. Yamamura, "Cyclophanes I", Topics in Current Chemistry No.113, ed. by F. Vögtle, Springer-Verlag, Berlin (1983) p. 145.

4) Y.Murakami, "Cyclophanes $I I$ ", Topics in Current Chemistry No. 115, ed. by F. Vögtle, Springer-Verlag, Berlin (1983) p. 107.

5) K. Odashima, K. Koga, "Cyclophanes", Vol. II, ed. by P. M. Keehn, S. M. Rosenfeld, Academic Press, New York (1983) Chapter 11.

6) M. L. Bender, M. Komiyama, "Cyclodextrin Chemistry", Springer-Verlag, Berlin (1978) p. 65

7) I. Tabushi, Acc. Chem. Res., 15, 66(1982).
炭化水素鎖を導入した「タコ」形フザシクロファン類は, 剛直な シクロファン骨格と柔軟性のある炭化水素鎖によって深みのある 蹯水性場を形成し，この部位が蹯水性ゲスト分子の認識にきわめ て有効であることを見いだしている8) 12)。この場合，ホスト分子 に種々の官能基を導入することによって柾水性相互作用，静電相 互作用, 電荷移動相互作用などによる分子識別が可能になり,

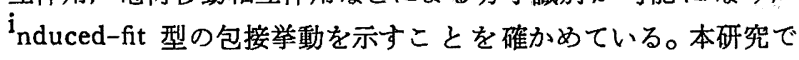
はこのような特異的ゲスト識別能を有する「タコ」形アザシクロ ファンの一つである $\mathrm{APC}\left(\mathrm{C}_{10} \mathrm{CO}_{2} \mathrm{H}\right)_{4}$ を取り上け゚，これをクロマ トグロフィー用担体に導入して新しい分離特性を発現しらるク口 マトグラフィー用充媜剤を開発することを目的とした。現在まで に，大環状型ホスト分子をクロマトグラフィーに応用した例はシ クロデキストリン18) 17), クラウンェーテル18)などに関して認め られるが、シクロファンを導入する手法は本研究が最初である。

8) Y. Murakami, A. Nakano, R. Miyata, Y. Matsuda, J. Chem. Soc., Perkin Trans. 1, 1979, 1669.

9) Y.Murakami, A. Nakano, K. Akiyoshi, K. Fukuya, ibid., 1981, 2800.

10) Y. Murakami, J. Kikuchi, M. Suzuki, T. Takaki, Chem. Lett., 1984, 2139.

11) Y. Murakami, J. Kikuchi, H. Tenma, ibid., 1985, 103.

12) Y. Murakami, Y. Hisaeda, J. Kikuchi, T. Ohno, M. Suzuki, Y. Matsuda, ibid., 1986, 727.

13) J. L. Hoffman, J. Macromol. Sci., Chem., A 7, 1147 (1973).

14) M. Tanaka, Y. Kawaguchi, M. Nakane, Y. Mizobuchi, T. Shono, J. Chromatogr., 246, 207(1982).

15) K. Fujimura, T. Ueda, T. Ando, Anal. Chem., 55, 446(1983). 
クロマトグラフィー用基盤担体として，市眅されているアフィ ニティークロマトグラフィー用の AF-アミノトヨパール 650 を 用いた。この担体はゲル沪過用充填剤として開発された親水性 のビニルポリマーであるトヨパール HW-65 に化学修飾によりア ミノ基を導入した誘導体であるが，厳しい反応条件下ですゲルが 安定であるため種々の化学修飾を施すことが可能であること，溶 離液として水以外の有機溶媒も使用でさること，高流速での使用 が可能であることなどの特徴を有している。ここでは, 均一水溶 液中に拈ける $\mathrm{APC}\left(\mathrm{C}_{10} \mathrm{CO}_{2} \mathrm{H}\right){ }_{4}$ とのホスト・ゲスト相互作用がす でに明らかにされている 6 種類の踈水性ゲスト分子に対して, 「タコ」形シクロファンを固定化した AF-アミノトョパール 650 を充填剤としたクロマトグラフィーを適用した場合の分離特性 を明らかにした。また「タコ」形シクロファンの担体への固定 化方法が異なる場合の分離能についても合わせて検討を行なっ た。

\section{2 実験}

\section{1. 測定機器類}

IR 扣よび ${ }^{1} \mathrm{H}-\mathrm{NMR}$ スペクトルの測定には，それぞれ日本分 光工業製 IR-810 型赤外分光光度計㧍よび日立製作所製 R-24 B 型核磁気共鳴装置を用いた。 $\mathrm{pH}$ の測定には Beckman 社製 39505 型複合電極を取り付けた $\Phi 71$ 型 $\mathrm{pH}$ メーターを使用した。 元素分析は九州大学中央元素分析所飞依頼した。

\section{2「タコ」形アザシクロファンの合成}

$N, N^{\prime}, N^{\prime \prime}, N^{\prime \prime \prime}$-テトラキス(10-カルボキシデシル) $-2,11,20$, 29-テトラアザ[3.3.3.3]パラシクロファン-1, 12, 19, 30-テトラオ ン $\left(\mathrm{APC}\left(\mathrm{C}_{10} \mathrm{CO}_{2} \mathrm{H}\right)_{4}\right)$ の合成は既報8)で述べた方法にしたがっ た。上記化合物の 4 個のカルボキシル基のらち 3 個をメチルエス テルとして保護した化合物の合成法を以下に述べる。

$N$-(10-カルボキシデシル) $-N^{\prime}, N^{\prime \prime}, N^{\prime \prime \prime}$-トリス(10-メトキシ カルボニルデシル) $-2,11,20,29$-テトラアザ[3.3.3.3]パラシクロ ファン-1, 12, 19; 30-テトラオン $\left(\mathrm{APC}\left(\mathrm{C}_{10} \mathrm{CO}_{2} \mathrm{H}\right)\left(\mathrm{C}_{10} \mathrm{CO}_{2} \mathrm{Me}\right)_{3}\right):$ $N, N^{\prime}, N^{\prime \prime}, N^{\prime \prime \prime}$-テトラキス(10-メトキシカルボニルデシル)-2, $11,20,29$-テトラアザ[3.3.3.3]パラシクロファン-1,12,19, 30-テ トラオン8) $1.0 \mathrm{~g}(0.76 \mathrm{mmol})$ をメタノール $(100 \mathrm{ml})$ に懸濁し, これに $0.2 \mathrm{~mol} \cdot \mathrm{dm}^{-3}$ 水酸化ナトリウム氷溶液 $(4 \mathrm{ml})$ を加えて 還流下で 10 時間かきまぜた。溶媒を減圧下に留去して得られた 固体にメタノール $(100 \mathrm{ml})$ を加之，不溶物を沪別した。承冷雨 に汇液に $1 \mathrm{~mol} \cdot \mathrm{dm}^{-3}$ 塩酸を加えて $\mathrm{pH}$ を 2 に調整し，析出した

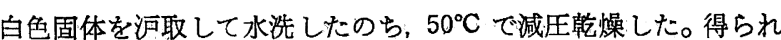
た固体についてゲルクロマトグラフィー（充填剤, トヨパール HW-40F ; 溶媒，メタノールークロロホルム $(1: 1 \mathrm{v} / \mathrm{v} \%))$ によ りくり返し精製を行ない白色固体を得た。収量, $69 \mathrm{mg}(7 \%)$ 。

IR $(\mathrm{KBr}) \nu_{\mathrm{C}=0}: 1742,1720,1620 \mathrm{~cm}^{-1}$ 。 $\mathrm{NMR}\left(\mathrm{CDCl}_{3}\right) \delta$ $(\mathrm{ppm}): 1.27\left(64 \mathrm{H}, \mathrm{m}, \mathrm{CH}_{2}\left(\mathrm{CH}_{2}\right)_{8} \mathrm{CH}_{2} \mathrm{CO}\right), 2.27\left(8 \mathrm{H}_{;}: \mathrm{t}\right.$,

16) W. L. Hinze, T.E. Riehl, D. W. Armstrong, W. De Mond, A. Alak, T. Ward, Anal Chem., 57, 237(1985).

17) I. Tabushi, T. Nabeshima, K. Yamamura, M. Tsuda, J. Org. Chem., 51, 1918(1986).

18) E. Blasius, K.-P. Janzen, "Host Guest Complex Chemistry I", Topics in Current Chemistry No.98, ed. byl F. Vögtle, Springer-Verlag, Berlin (1981) p. 163 ; references cited therein.
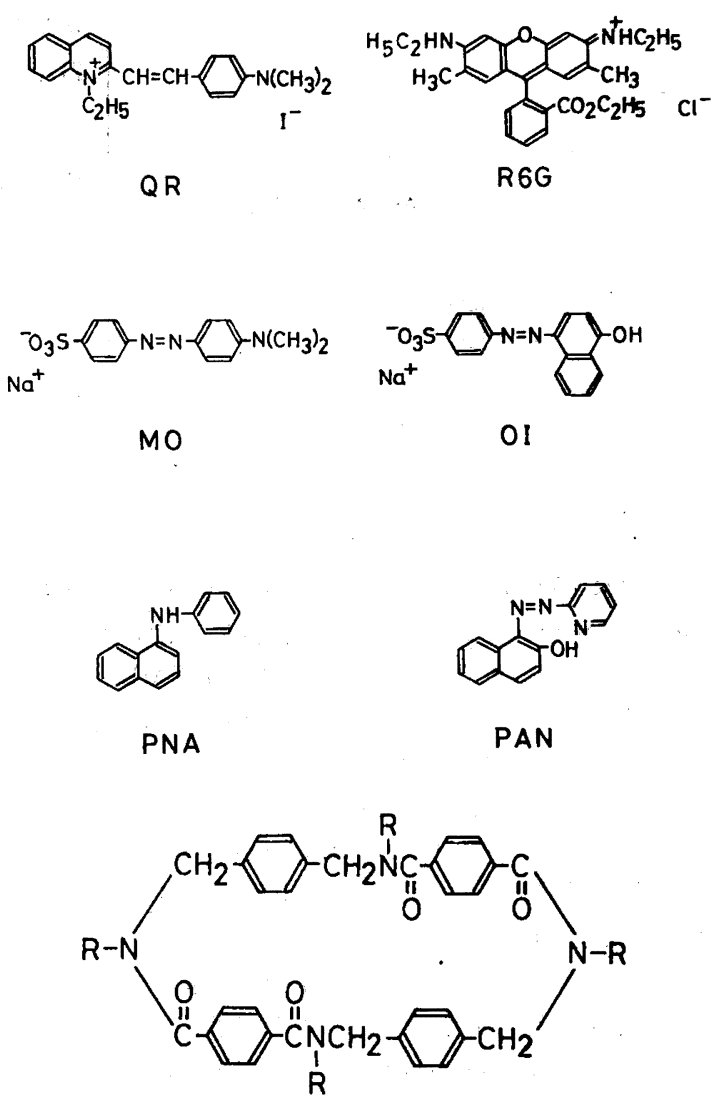

$\operatorname{APC}\left(\mathrm{C}_{10} \mathrm{CO}_{2} \mathrm{H}\right)_{4}$ $\mathrm{R}=\left(\mathrm{CH}_{2}\right)_{10} \mathrm{CO}_{2} \mathrm{H}$ $\operatorname{APC}\left(\mathrm{C}_{10} \mathrm{CO}_{2} \mathrm{H}\right)\left(\mathrm{C}_{10} \mathrm{CO}_{2} \mathrm{Me}\right)_{3}$

$\mathrm{R}_{1 / 4}=\left(\mathrm{CH}_{2}\right)_{10} \mathrm{CO}_{2} \mathrm{H}$

$\mathrm{R}_{3 / 4}=\left(\mathrm{CH}_{2}\right)_{10} \mathrm{CO}_{2} \mathrm{CH}_{3}$

$\left.\mathrm{CH}_{2} \mathrm{CO}\right)$, 3. $50\left[8 \mathrm{H}, \mathrm{m}, \mathrm{NCH}_{2}\left(\mathrm{CH}_{2}\right)_{9} \mathrm{CO}\right], 3.60\left(9 \mathrm{H}, \mathrm{s}, \mathrm{CH}_{8}\right)$, $4.45(8 \mathrm{H}$, br s, ペンジル位水素)， $7.12(16 \mathrm{H}, \mathrm{m}$ ，芳香䓡水 素)。

分析値 C $71.76 \%, \mathrm{H} 8.73 \%, \mathrm{~N} 4.22 \%$

$\mathrm{C}_{79} \mathrm{H}_{114} \mathrm{~N}_{4} \mathrm{O}_{12} \cdot 1 / 2 \mathrm{H}_{2} \mathrm{O}$ としての

計算値 C $71.84 \%, \mathrm{H} 8.78 \%, \mathrm{~N} 4.24 \%$

2.3「タコ」形アザシクロフォンのゲル汇過用担体への固定化

クロマトグラフィー用担体として AF-フミントヨパール 650 （東洋曹達工業製；膨潤ゲル $1 \mathrm{ml}$ あたりのアミノ基含量 180 $\mu \mathrm{mol}$ ) を用い, 図式 1 に示す 3 とおりの方法でアザシクロフォン の導入を行なった。

2.3.1 AF-アミノトヨハーール 650 に $\mathrm{APC}\left(\mathrm{C}_{10} \mathrm{CO}_{2} \mathrm{H}\right)_{4}$ を直接 導入する方法: AFーアミノトヨパール 650 をガラス沪過器 (G 2) 上で蒸留水，ついで $1 \mathrm{~mol} \cdot \mathrm{dm}^{-8}$ 塩酸にて $\mathrm{pH}$ を 4 に調整した蒸 留水で十分に洗浄したのち， pH 4 の蒸留水中で膨洞させた。こ の $5 \mathrm{ml}$ をジオキサンー水 $(4: 3 \mathrm{v} / \mathrm{v} \% ; 60 \mathrm{ml})$ に緜濁し, $\mathrm{pH} 4$ に 調整した。 $\mathrm{APC}\left(\mathrm{C}_{10} \mathrm{CO}_{2} \mathrm{H}\right)_{4} 64 \mathrm{mg}(50 \mu \mathrm{mol})$ をジオキサン（20 $\mathrm{m} l)$ に溶解し、これに蒸留水 $(15 \mathrm{ml})$ を加えて $\mathrm{pH} 4$ に調整した 溶液を上記ゲル眯濁液に加えた。この混合物に，N-ェチル- $N^{\prime}-$ (3-シメチルフミノプロピル)カルボジイミド塩酸塩 (以下 EDC と略記する) $111 \mathrm{mg}(580 \mu \mathrm{mol})$ を含む $\mathrm{pH} 4$ の水容液 $(4 \mathrm{ml})$ 


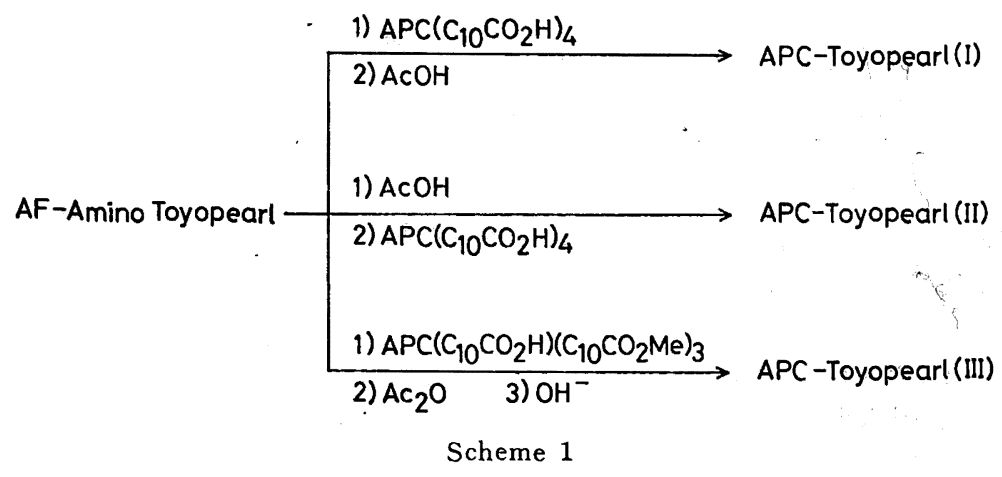

を加えて室温で 10 時間稳やかにふりりぜた。その後ゲルを沪 取し, 蒸留水 $(50 \mathrm{ml})$, ジオキサン一水 $(2: 1 \mathrm{v} / \mathrm{v} \% ; 50 \mathrm{ml})$ で順 次洗浄した。沪液求よびそれぞれの洗浄液から溶媒を留去して得 られた残留物について IR(KBr) および ${ }^{1} \mathrm{H}-\mathrm{NMR}$ スペクトル

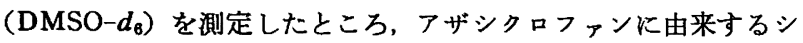
グナルはまったく検出されなかったことから， $\mathrm{APC}\left(\mathrm{C}_{10} \mathrm{CO}_{2} \mathrm{H}\right)_{4}$ はすべてゲルに結合したすのと判断した。このゲルをさらに蒸留 水で洗浄したのち, 酢酸 $64 \mathrm{mg}(1.1 \mathrm{mmol})$ を含む $\mathrm{pH} 4$ の水溶 液 $(20 \mathrm{ml})$ に懸濁し，これに $\mathrm{EDC} 1.3 \mathrm{~g}(6.8 \mathrm{mmol})$ を含む $\mathrm{pH} 4$ の水溶液 $(4 \mathrm{ml})$ を加えて室温で 17 時間稳やかにふりまぜ た。その後、ゲルを沪取し蒸留水で十分に洗浄した。ゲルのニン ヒドリン試験を行ない陰性であることを確認した。ここで得られ たゲルを以下 APC-Toyopearl（Ｉ）と略記する。

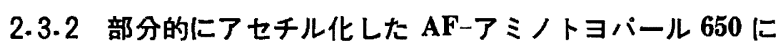
$\mathrm{APC}\left(\mathrm{C}_{10} \mathrm{CO}_{2} \mathrm{H}\right)$ 、を導入する方法 : $\mathrm{AF}$ ーアミノトヨパール 650 を ガラス沪過器 (G 2) 上で蒸留水, ついで $\mathrm{pH} 4$ に調整した蒸留水 で十分に洗浄したのち，pH 4 の蒸留水中で膨潤させた。この 5 $\mathrm{m} l$ を酢酸 $51 \mathrm{mg}(850 \mu \mathrm{mol})$ を含む $\mathrm{pH} 4$ の水溶液 $(20 \mathrm{ml})$ に 懸濁し，これに EDC $1.6 \mathrm{~g}(8.4 \mathrm{mmol})$ を含む $\mathrm{pH} 4$ の水溶液 $(4 \mathrm{ml})$ を加えて室温で 12 時間穏やかにふりまぜた。ゲルを沪取 し, 蒸留水で十分に洗浄したのちジオキサンー水 $(4: 3 \mathrm{v} / \mathrm{v} \% ； 60$ $\mathrm{ml})$ に懸濁して pH 4 に調整たし。 $\mathrm{APC}\left(\mathrm{C}_{10} \mathrm{CO}_{2} \mathrm{H}\right)_{4} 64 \mathrm{mg}(50$ $\mu \mathrm{mol})$ をジオキサン $(20 \mathrm{ml})$ に溶解し，これに蒸留水 $(15 \mathrm{ml})$ を 加えて pH 4 に調整した溶液を上記ゲル懸濁液に加えた。この混 合物に EDC $109 \mathrm{mg}(570 \mu \mathrm{mol})$ を含む $\mathrm{pH} 4$ の水溶液 $(4 \mathrm{ml})$ を加えて室温で 10 時間穞やかにふりまぜた。その後，ゲルを沪 取して蒸留水 $(50 \mathrm{ml})$, ジオキサンー水 $(2: 1 \mathrm{v} / \mathrm{v} \% ; 50 \mathrm{ml})$, 蒸 留水 $(50 \mathrm{ml})$ で順次洗浄した。この場合にも $\mathrm{APC}\left(\mathrm{C}_{10} \mathrm{CO}_{2} \mathrm{H}\right)_{4}$ は すべてゲルに固定化されたことを，沪液と洗浄液から溶媒を留去 にして得られたそれぞれの残留物について IR および ${ }^{1} \mathrm{H}-\mathrm{NMR}$ スペクトルを測定することにより確認した。また，ゲルの二ンヒ ドリン試験は陰性であった。ここで得られたゲルを以下 APCToyopearl(II) と略記する。

2.3.3 AF-アミノトヨハーール650に $\mathrm{APC}\left(\mathrm{C}_{10} \mathrm{CO}_{2} \mathrm{H}\right)\left(\mathrm{C}_{10} \mathrm{CO}_{2}\right.$ • Me) ${ }_{3}$ として等入する方法: AF-アミノトヨパール 650 をガラス 沪過器 (G 2) 上で蒸留水, ついで pH 4 に調整した蒸留水で十分に 洗浄したのち， $\mathrm{pH} 4$ の蒸留水中で膨潤させた。この $5 \mathrm{~m} l$ をジオ キサンー水 $(3: 2 \mathrm{v} / \mathrm{v} \% ; 80 \mathrm{ml})$ に䅗濁し $\mathrm{pH} 4$ に調整した。APC$\left(\mathrm{C}_{10} \mathrm{CO}_{2} \mathrm{H}\right)\left(\mathrm{C}_{10} \mathrm{CO}_{2} \mathrm{Me}\right)_{3} 66 \mathrm{mg}(50 \mu \mathrm{mol})$ をジオキサン $(5 \mathrm{ml})$ に溶解し,これに蒸留水 $(2 \mathrm{ml} l)$ を加えて $\mathrm{pH} 4$ に調整した溶液
を上記のゲル懸濁液に加えた。この混合物に EDC $340 \mathrm{mg}(1.8$ $\mathrm{mmol})$ を含む $\mathrm{pH} 4$ の水溶液 $(4 \mathrm{ml})$ を加之て室温で 21 時間穏 やかにふりまぜた。その後, ゲルを汇取し蒸留水 $(50 \mathrm{ml})$, ジオ キサンー水 $(3: 2 \mathrm{v} / \mathrm{v} \% ; 50 \mathrm{ml})$ で順次洗浄した。ジオキサンー水 による洗浄液からは未反応のアザシクロファンを $7 \mathrm{mg}$ 回収し た。このゲルをさらに $0.2 \mathrm{~mol} \cdot \mathrm{dm}^{-3}$ 酢酸ナトリウム水溶液 $(70$ $\mathrm{ml}$ ) で洗浄したのち, $0.2 \mathrm{~mol} \cdot \mathrm{dm}^{-3}$ 酢酸ナトリウム水溶液 (40 $\mathrm{ml})$ に懸濁した。これに無水酢酸 $(20 \mathrm{ml})$ を加えて $0^{\circ} \mathrm{C} て ゙ 30$ 分 間放置し,さらに無水酥酸 $(20 \mathrm{~m} l)$ を加えて室温で 1 時間放置し た。その後, ゲルを沪取して蒸留水 $(100 \mathrm{ml}), 0.2 \mathrm{~mol} \cdot \mathrm{dm}^{-3}$ 水 酸化ナトリウム水溶液 $(100 \mathrm{ml})$, 蒸留水 $(100 \mathrm{ml})$ で順次洗浄し た。ダルのニンヒドリン試験は陰性であった。これをメタノール $(80 \mathrm{ml})$ ：懸濁し, $1 \mathrm{~mol} \cdot \mathrm{dm}^{-3}$ 水酸化なトリウム水溶液 $(10 \mathrm{ml})$ を加えて 13 時間還流を行ないアザシクロファンのメチルエステ ル基を加水分解した。ゲルを沪取して蒸留水， $0.01 \mathrm{~mol} \cdot \mathrm{dm}^{-3}$ 塩 酸, 蒸留水で順次洗浄した。ここで得られたゲルを APC-Toyo$\operatorname{pearl}(\mathrm{III})$ と略記する。

一方、アザシクロファンを導入していない参照用のゲルとし て，アミノ基をすべてアセチル化した AF-アミノトヨパール 650 (以下 Ac-Toyopearl と略記する) を aminoethyl Bio-Gel P 150 や amino-Sepharose 4 B のアミノ基をアセチル化する方法 ${ }^{1920)}$ にしたがって調製した。得られたゲルはニンヒドリン試験が陰性 であることを確認した。

\section{4 クロマトクラフィーによるゲスト分子の分離}

2.3 で調製したゲル (APC-Toyopearl（I），(II)，(III)および Ac-Toyopearl）をそれぞれ内径 $6.0 \mathrm{~mm}$ のガラス製カラムに 160 $\mathrm{mm}$ の長さに充媜した。溶離液としては $0.01 \mathrm{~mol} \cdot \mathrm{dm}^{-3}$ の炭酸 緩衝液 (pH 10.0， $\mu 0.10(\mathrm{KCl})$ ) とメタノールの混合溶媒を用 い, 分離能の測定はすべて室温 $\left(20 \pm 1^{\circ} \mathrm{C}\right)$ で行なった。 1.0 $\mathrm{mmol} \cdot \mathrm{dm}^{-3}$ の各試料溶液 $(30 \mu l)$ をカラムに注入し, 流速は ペリスタポンプ (ミツミ科学産業製) で $1.0 \mathrm{ml} \cdot \mathrm{min}^{-1}$ に調整し た。溶離成分の検出には紫外分光光度計（日本分光工業製 UVIDEC-100 型) を用いた。ブルーデキストラン 2000 (Pharmacia 社）の保持時間はいずれのカラムについてもすべて $4.7 \pm 0.1$ 分間であった。 $N$-フェニル-1-ナフチルアミン (PNA；東京化成 工業 1 級試薬) はメタノール-水 $(4: 1 \mathrm{v} / \mathrm{v})$ から再結晶 $(\mathrm{mp}$

19) R. J. Baues, G. R. Gray, J. Biol. Chem., 252, 57 (1977).

20) I. Matsumoto, H. Kitagaki, Y. Akai, Y. Ito, N. Seno, Anal. Biochem., 116, 103(1981). 
$61 \sim 62^{\circ} \mathrm{C}$ ) したものを用いた。また，以下の化合物は高純度の市 肘品を䞂入してそのまま使用した：ローダミン $6 \mathrm{G}$ (2-(6-エチ ルアミノ-3-エチルイミニオ-2,7-ジメチル-3 H-キサンテン-9イル)安息香酸エチルクロリド) (R6 G ; キシダ化学), キナルジ ンレッド (2-(p-ジメチルアミノスチリル)-1-エチルキノリニウ ムヨージド) (QR ; 半井化学薬品), 1-(2-ピリジルアゾ)-2-ナフ トール (PAN ; 同仁化学研究所), メチルオレンジ (4-ジメチルア ミノアゾベンゼン-4'-スルホン酸ナトリウム)（MO；和光純薬工 業), オレンジI (p-(4-ヒドロキシ-1-ナフチルフゾ)ベンゼンス ルホン酸ナトリウム) (OI ; 半井化学薬品)。

\section{3 結果と考察}

$3.1 「 タ コ 」$ 形アザシクロファンの分子認識特性とクロマトク ラフィー用担体への固定化

テトラアザ[3.3.3.3]パラシクロファン骨格に 4 本のウンデカ ン酸部位を導入した「タコ」形アザシクロファンである APC$\left(\mathrm{C}_{10} \mathrm{CO}_{2} \mathrm{H}\right)_{4}$ は, $\mathrm{pH} 10$ の水溶液中に扎いて陰イオン性ホスト分 子として挙動し, 陽イオン性および非イオン性の柾水性ゲスト分 子に対して強い包接能を示す。たとえば, 陽イオン性ゲストであ るローダミン $6 \mathrm{G}$ (以下 R6 G と略記する) とキナルジンレッド (以下 $Q R$ と略記する)をゲスト分子としたとさの 1 対 1 複合体の 安定度定数はそれぞれ $4.8 \times 10^{3}$ および $4.5 \times 10^{3} \mathrm{~mol}^{-1} \cdot \mathrm{dm}^{3}$ であ

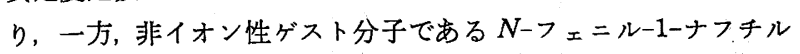
アミン (以下 PNA と略記する) と 1-(2-ピリジルアゾ)-2-ナフ トール (以下 PAN と略記する) との安定度定数はそれぞれ 1.6 $\times 10^{3}$ および $1.5 \times 10^{3} \mathrm{~mol}^{-1} \cdot \mathrm{dm}^{8}$ である ${ }^{8111)}$ 。れに対して, 陰 イオン性ゲスト分子であるメチルオレンジ（以下 MO と略記す る）およびオレンジ I（以下ＯＩと略記する）などに対してはま ったく包接能を示さない。したがって, $\mathrm{APC}\left(\mathrm{C}_{10} \mathrm{CO}_{2} \mathrm{H}\right)_{4}$ は静電相 互作用と疎水性相互作用によってゲスト分子を識別しており，と くに 2 種類の相互作用が協同的に働くと考えられる陽イオン性ゲ ストに対してその包接能は顕著である。また, $\mathrm{APC}\left(\mathrm{C}_{10} \mathrm{CO}_{2} \mathrm{H}\right)_{4}$ よりも短い炭化水素鎖長をむつアザシクロファンである $N, N^{\prime}$, $N^{\prime \prime}, N^{\prime \prime \prime}$-テトラキス(2-カルボキシェチル)-2, 11, 20, 29-テトラ アザ[3.3.3.3]パラシクロファン-1, 12,19,30-テトラオンでは, 陽イオン性お゙よび非イオン性の柾水性ゲストに対しても取り込み がほとんど認められないことから ${ }^{11}, \operatorname{APC}\left(\mathrm{C}_{10} \mathrm{CO}_{2} \mathrm{H}\right)_{4}$ に打いて は剛直なアザシクロファン骨格と 4 本の柔軟性のある炭化水素鎖 によって構成される深みのある疎水性空間が有効な分子認識の場 として働いていることは明らかである。

このような特異的ゲスト認識能を有する「タコ」形アザシクロ ファンをクロマトグラフィー用担体に導入することによって, 従 来のクロマトグラフィーでは認められない新たな分離特性の発現 が期待される。クロマトグラフィー用担体である AF-アミノト ヨパール 650 ヘアミド結合を介してアザシクロファンを固定化 するために，つぎの 3 と拈りの方法を適用した。第一は，APC$\left(\mathrm{C}_{10} \mathrm{CO}_{2} \mathrm{H}\right)_{4}$ を水溶性の縮合剤である EDC を用いて直接導入す る方法である。「タコ」形アザシクロファンの包接特性をでき得 るかぎり保持したまま固定化するには，1 分子あたり 1 個のカル ボキシル基のみを反応させることが望ましいが（図19模式図参 照), この方法では複数のカルポキシル基が反応する可能性が高 い。第二は， AF-アミノトヨパール 650 中のアミノ基を部分的に

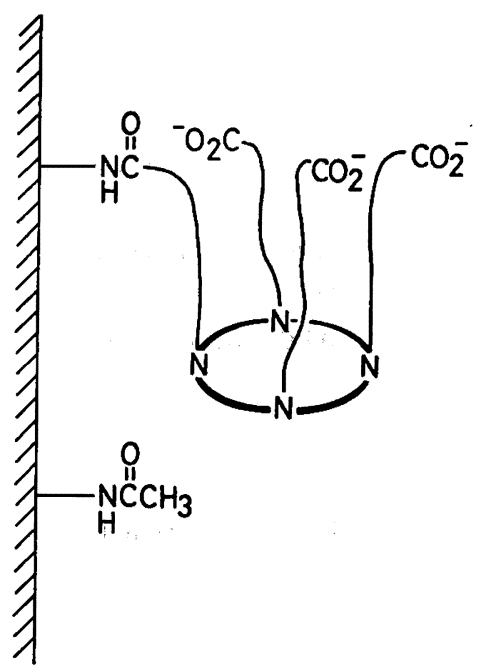

Fig. 1 Schematic representation of gel surface to which octopus-like azacyclophane is chemically bound

アセチル化したのちに $\mathrm{APC}\left(\mathrm{C}_{10} \mathrm{CO}_{2} \mathrm{H}\right)_{4}$ を結合させる方法であ り，第一の方法にくらべれば 1 分子あたり複数のカルボキシル基 が反応する割合は少なくなると考兄られる。これに対して，第三 の方法では, $\mathrm{APC}\left(\mathrm{C}_{10} \mathrm{CO}_{2} \mathrm{H}\right)_{4}$ の 4 個のカルボキシル基の5ち 3 個をメチルエステルとして保護した化合物である $\mathrm{APC}\left(\mathrm{C}_{10} \mathrm{CO}_{2-}\right.$ H) $\left(\mathrm{C}_{10} \mathrm{CO}_{2} \mathrm{Me}\right)_{3}$ を用いて AF-アミノトヨパール 650 との縮合 反応を行ない，その後ェステルを加水分解する処理を行なってい る。この場合には，アザシクロファンの結合様式はきわめて明確 であり，図1に示すような結合様式で担体に固定化しているるの といえる。第一拉よび第二の方法を適用した場合には反応に用い たアザシクロファンはすべて担体に固定化されてお゙り，膨潤ゲル $1 \mathrm{ml}$ あたり $10 \mu \mathrm{mol}$ のアザシクロファンが固定化された。一方, 第三の方法を用いて反応を行なった場合では一部未反応の APC$\left(\mathrm{C}_{10} \mathrm{CO}_{2} \mathrm{H}\right)_{4}$ が回収されており, 固定化量は膨潤ゲル $1 \mathrm{ml}$ あたり $9 \mu \mathrm{mol}$ であった。いずれの方法を用いた場合にも担体中の残存 アミノ基がゲスト分子の識別におよぼす影響を排除するために, 末反応のアミ/基はすべてアセチル化しており，このことはニン ヒドリン試験が陰性であることにより確認した。さらに, このよ らにして調製したクロマトグラフィー用充填剈のアザシクロファ ン導入効果を評価するために, アミノ基をすべてアセチル化した

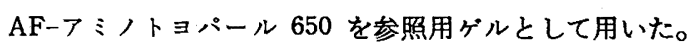

\section{2 クロマトグラフィーによる分離特性}

「タコ」形アザシクロファンの固定化方法が異なる 3 種類の充 填剂 APC-Toyopearl( I ), (II)，（III）とAc-Toyopearl をそれ ぞれ充填したカラムを用いて，均一水溶液中で $\mathrm{APC}\left(\mathrm{C}_{10} \mathrm{CO}_{2} \mathrm{H}\right)$ 4 とのホスト・ゲスト相互作用が明らかにされているゲスト分子の 分離特性について検討した。

まず,それぞれのカラムの充媜状態を調べるために，平均分子 量が $2 \times 10^{8}$ のブルーデキストラン 2000 を基準物質に選んで各 カラムの保持時間（以下 $t_{\mathrm{R}}$ と略記する）を湘定した。いずれ のカラムも担体べッドの全容量は同一であり, 流速を $1.0 \mathrm{ml}$. $\mathrm{min}^{-1}$ で一定にした場合には $t_{\mathrm{R}}$ 值はすべて $4.7 \pm 0.1 \mathrm{~min}$ であ った。また，本研究ではメタノールと炭酸緩衝液の混合溶媒を 


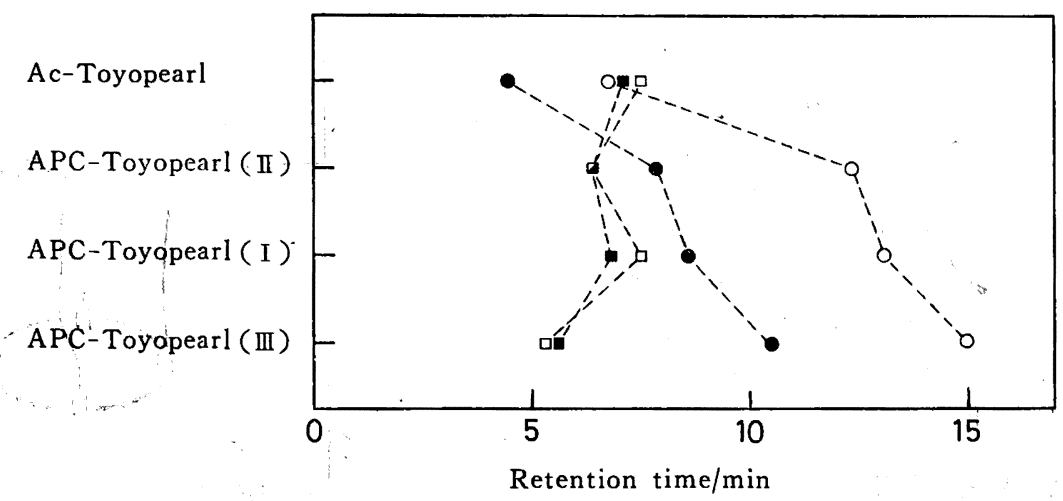

Fig. 2 Retention times for hydrophobic guest compounds as chromatographed on columns of Ac-Toyopearl, APC-Toyopearl(I), (II), and (III) at $20^{\circ} \mathrm{C}$ : Rhodamine 6G (O), Quinaldine Red (O), Methyl Orange ( $)$, Orange $\mathrm{I}(\square)$; eluant, methanol-aqueous carbonate buffer $\left(0.01 \mathrm{~mol} \cdot \mathrm{dm}^{-3}, \mathrm{pH}\right.$ $10.0, \mu 0.10$ with $\mathrm{KCl}$ ) at $40: 60 \mathrm{v} / \mathrm{v} \%$

溶䧹液として用い,その組成を $50: 50(\mathrm{v} / \mathrm{v} \%)$ から $35: 65(\mathrm{v} / \mathrm{v}$ \%) の間で変化させたが，いずれのカラムについてもブルーデキ ストラン 2000 の $t_{\mathrm{R}}$ 值にはまったく变化が認められなかった。. 以上のことは，担体に導入した「タコ」形アザシクロファンが構 成する疎水性場は高分子物質であるブルーデキストラン 2000 に 対しては認識部位としての機能を発現できないことを反映してい ると考えられる。また, 各カラムについて容量比 (capacity factor）の算出に必要な排除容量（void volume）を正確に見積もる ことは困難であったが，上述のようにブルーデキストラン 2000 の $t_{\mathrm{R}}$ 值が同じであったことから，以下の低分子ゲストに対する 分離能の比較はそれぞれの $t_{\mathrm{R}}$ 值によって行なった。

固定化方法が異なるアザシクロファン導入ゲルの分離機能につ いて，4 種類のイオン性ゲスト分子を用いて比較検討した。罒 2 に示すよらに, 溶離液組成がメタノール-炭酸緩衝夜 $(40: 60 \mathrm{v} / \mathrm{v}$ \%) の場合には，アザシクロファンを導入していない:Ac-Toyopearl を充媜したカラムにくらべて APC-Toyopearl を充填した カラムでは分離機能に大きな差異が認められた。すなわち，陽イ オン性の R6G と $\mathrm{RR}$ の溶離はアザシクロファンの導入によっ てて，いずれのカラムにおいてもいちじるしく抑制されるが，陰 イオン性の MO とO I の溶離は幾分促進された。この傾向は APC-Toyopearl( I ) および(II)にくらべて APC-Toyopearl( III) についてもっとも顕著であり，この第三のゲルの場合にアザシク ロファンのもつ「タコ足」の効果がもっとも効果的に発現されてい ることを示すすのである。ここで認められた分離挙動は, 3.1 に おいて述べた $\mathrm{APC}\left(\mathrm{C}_{10} \mathrm{CO}_{2} \mathrm{H}\right)_{4}$ の水溶液中に批ける包接挙動によ く対俯しており、「タコ」形アザシクロファンのゲスト分子識別 能がクロマトグラフィーによっても有効に発現されたことを意味 している。また, APC-Toyopearl（I）および(II)の調製にさいし ての「タコ」形フザシクロファンの固定化法の相違は, クロマト グラフィーによる分離举動には大きな差異として現われなかっ た。以下の実験に打いては,アザシクロファンの効果がもっとも 大きく現われた APC-Toyopearl(II) を用いて, Ac-Toyopearl との分雄機能の比較について詳細に検討した。

図 3 Kは Ac-Toyopearl とAPC-Toyopearl(III) を充填したカ ラムについて，溶離液組成を変化させた場合のイオン性ゲスト分
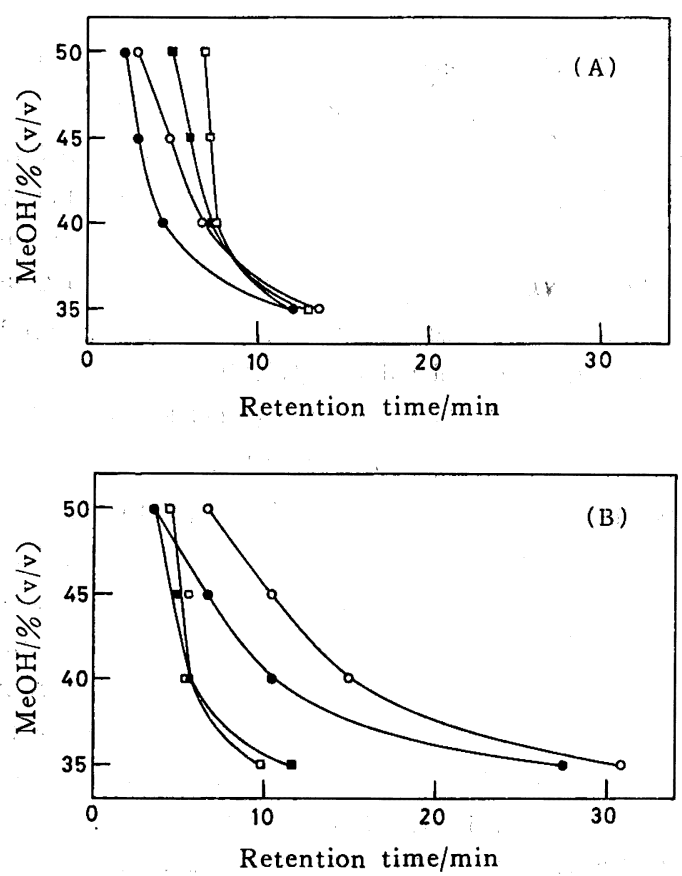

Fig. 3 Correlations of eluant composition with retention time for various hydrophobic guest compounds as chromatographed on columns of Ac-Toyopearl (A) and APC-Toyopearl(iII) (B) at $20^{\circ} \mathrm{C}$ : Rhodamine $6 \mathrm{G}$ (O), Quinaldine Red (O), Methyl Orange ( $\mathbf{G})$, Orange I $(\square)$; eluant, methanolaqueous carbonate buffer $\left(0.01 \mathrm{~mol} \cdot \mathrm{dm}^{-3}, \mathrm{pH} 10.0\right.$, $\mu 0.10$ with $\mathrm{KCl}$ )

子の $t_{\mathrm{R}}$ 值をそれぞれ示した。Ac-Toyopearl の場合には， $50 \%$ $(\mathrm{v} / \mathrm{v})$ メタノールを溶離液としたときの $t_{\mathrm{R}}$ 值は $\mathrm{R} 6 \mathrm{G}, \mathrm{QR}$, MO，O I の順に增大した。陽イオン性分子は分子径の大きい順 序に溶出していることがらかがえるが，陰イオン性分子の場合は これとは逆の傾向が認められる。测定条件下（pH 10.0）におい てMOは一洒陰イオン性ゲストであるのに対し，OIは二価陰イ オンとして举動する（OＩの 1-位ヒドロキシル基の $p K_{\mathrm{a}}$ 值は 
8.2 である $\left.{ }^{21)}\right)$ 。また，上述のように陰イオン性色素であるチバク ロンブルー 3G-A (1-アミ)-4-[[4-[[4-クロロ-6-[(3または 4スルホナトフェニル) アミノ]-1,3,5-トリアシシン-2-イル]アミ ノ]-3-スルホナトフェニル]アミノ]-9, 10-ジヒドロ-9,10-ジオキ ソー2-フントラセンスルホン酸トリナトリウム) を固定化してい るデキストランである221 ブルーデキストラン 2000 も分子径か ら予测されるよりかなり掘く溶出していることから，Ac-Toyopearl は陰イオン性分子と何らかの特異的相互作用をむつものと 推察される。さらに，溶離液のメタノール含量を減少させるとと もに $t_{\mathrm{R}}$ 值はいずれのゲスト分子の場合にも增大し，4種類のイ オン性分子に対する分離能は低下したが，これは担体とゲスト分 子との疎水性相互作用が支配的になったことを反映しているもの と考えられる。このような蹯水性相互作用による分離㤝，非イオ ン性分子である PNA やPAN の場合には, $50 \%$ (v/v) メタノー ルを溶離液とした場合にも顕著に認められた（表 1)。

$50 \%(\mathrm{v} / \mathrm{v})$ メタノールを含む溶離液を用いた場合のこれらのゲ スト分子の $t_{\mathrm{R}}$ 值は, APC-Toyopearl(III) を充填したカラムでは Ac-Toyopearl の場合にくらべて，非イオン性および陽イオン性 分子については增大し，一方，陰イオン性ゲスト分子については 減少した（表 1)。したがって，APC-Toyopearl（III）は明らか に, 静電相互作用と疎水性相互作用による新たな分離特性を発現 していることがわかる。このような分離特性は，イオン性ゲスト 分子に対して, 溶離液のメタノール含量を $35 \sim 50 \%(\mathrm{v} / \mathrm{v})$ の範 囲で変化しても同様に認められた（図3)。これに対して，非イオ ン性ゲスト分子については溶離液のメタノール含量を低下させる と $t_{\mathrm{R}}$ 值はいちじるしく増大するとともに溶泾ピークが幅広にな り，正確な值の算出は困䧼であった。

さらに, 図 3 B K示すように, APC-Toyopearl(II) の陽イオ ン性ゲストと陰イオン性ゲストとの分離能は溶離液のメタノール 含量が多い場合にはそれほど顕著ではないが, メタノール含量の 減少とともに次第に增大した。この挙動は, 担体に固定化された 「タコ」形アザシクロファンのカルボキシレート部位は単純な静 電相互作用で陽イオン性ゲストの滞留時間を大きくしているので はなく，アザシクロファンの 4 本の炭化水素鎖の疎水性相互作用

21）大河原 信, 北尾悌次郎, 平嶋恒亮, 松岡 賢編, “色素 ヘンドブック”, 講談社 (1986) p. 187.

22) P. Röschlau, B. Hess, Hoppe-Seyler's Z. Physiol. Chem., 353, 441(1972).
Table 1 Retention times for hydrophobic guest compounds as chromatographed on columns of APC-Toyopearl (II) and Ac-Toyopearl at 20 ${ }^{\circ} \mathrm{C}$ a)

\begin{tabular}{ccc} 
Guest & \multicolumn{2}{c}{$t_{\mathrm{R}} / \mathrm{min}$} \\
\cline { 2 - 3 } & APC-Toyopearl(II) & Ac-Toyopearl \\
\hline PNA & 66.0 & 63.0 \\
PAN & 13.5 & 12.0 \\
QR & 6.8 & 3.8 \\
R 6 G & 3.8 & 2.3 \\
MO & 3.0 & 4.9 \\
O I & 4.5 & 6.8
\end{tabular}

a) Eluant : Methanol-aqueous carbonate buffer (0.01 $\mathrm{mol} \cdot \mathrm{dm}^{-3}, \mathrm{pH} 10.0, \mu 0.10$ with $\left.\mathrm{KCl}\right)$ at $50: 50$ $\mathrm{v} / \mathrm{v} \% \cdot \mathrm{r}$

によって棈成される深みのある疎水性場に陽イオン性ゲスト分子 が蹯水性相互作用と静電相互作用の協同効果によって有効に包接 されたことを意味するものでありこの効果によって有効な分漓 が行なわれたことを示している。

\section{4 結 論}

蹯水性相互作用と静電相互作用によってゲスト分子を識別でき る「タコ」形アザシクロファンである $\mathrm{APC}\left(\mathrm{C}_{10} \mathrm{CO}_{2} \mathrm{H}\right)_{4}$ は induced-fit 型の特異な包接特性を有しているが, このホスト分子を $\mathrm{AF}-ア ミ ノ ト ヨ ハ ゚ ー ル 650$ に固定化することによって，「タコ」 形アザシクロファンのゲスト識別特性を反映した分離機能を示す 新規クロマトグラフィー用充填剤を開発できた。本研究で用いた クロマトグラフィー用担体はそれ自体である程度聶水性相互作用 による分離特性を有しており，今後，親水性がさらに大きい担体 を用いることによって「タコ」形シクロファンによる分離特性を さらに強調できるものと期待される。「タコ」形アザシクロファ ンの水溶液中におけるゲスト認識能は，炭化水素鎖の数を増した 8 本鎖型アザシクロファンに打いてはさらにいちじるしく高めら れることが明らかになっており ${ }^{101212)}$ このよらなホスト分子の導 入によって高度な分子識別能をむつクロマトグラフィー用担体の 開発も可能になるといえよう。

本研笔を行ならにあたって研究費の一部を矢畸科学技術振與記 念財団からこ援助いたたいた。ここに深く謝意を表したい。 


\title{
Special Articles on \\ Molecular Recognition and Its Application
}

\author{
Characteristic Molecular Recognition by an Octopus-like Azacyclophane \\ and Its Application to Chromatographic Separation \\ Yukito Murakami*, Jun-ichi Kikuchi and Takeo Matsuura \\ Department of Organic Synthesis, Faculty of Engineering, Kyushu University; \\ Hakozaki, Higashi-ku, Fukuoka-shi 812 Japan.
}

\begin{abstract}
An octopus-like azacyclophane having four flexible hydrocarbon chains on the rigid macrocyclic skeleton, $N, N^{\prime}, N^{\prime \prime}, N^{\prime \prime \prime}$-tetrakis(10-carboxydecyl)-2, 11, 20, 29-tetraaza[3. 3. 3. 3]paracyclophane-1,12,19, 30-tetraone $\left(\mathrm{APC}\left(\mathrm{C}_{10} \mathrm{CO}_{2} \mathrm{H}\right)_{4}\right)$, was immobilized on the AF-amino Toyopearl 650 gel. The following hydrophobic guest molecules, whose binding behaviors toward $\mathrm{APC}\left(\mathrm{C}_{10} \mathrm{CO}_{2} \mathrm{H}\right)_{4}$ in homogeneous aqueous solutions have been clarified, were chosen for chromatographic separation ; cationic Quinaldine Red and Rhodamine 6 G, anionic Methyl Orange and Orange I, and nonionic $N$-phenyl-1-naphthylamine and 1-(2-pyridylazo)-2naphthol. The chromatographic separation of these guest compounds was performed on the azacyclophane-bonded stationary phase by using eluants composed of methanol and aqueous carbonate buffer $\left(0.01 \mathrm{~mol} \cdot \mathrm{dm}^{-3}, \mathrm{pH} 10.0, \mu 0.10\right.$ with $\left.\mathrm{KCl}\right)$ at various ratios. The separation efficiency of the stationary phase is correlated with the inclusion ability of the octopus-like azacyclophane, which is primarily controlled by hydrophobic and electrostatic interactions between the host molecule and the guest molecules (Table 1 and Fig. 3). When only one carboxyl group was exclusively bound to the AF-amino Toyopearl 650 gel by protecting the rest of the carboxyl groups of $\mathrm{APC}\left(\mathrm{C}_{10} \mathrm{CO}_{2} \mathrm{H}\right)_{4}$ as the methyl esters, selective molecular recognition by the modified stationary phase was most enhanced relative to other modified ones which were prepared by direct immobilization of $\operatorname{APC}\left(\mathrm{C}_{10} \mathrm{CO}_{2} \mathrm{H}\right)_{4}$ on the Toyopearl gel.
\end{abstract}

